\title{
MULTI-STATE TAXATION OF PERSONAL INCOME
}

In the past two decades, the personal income tax has become an increasingly important source of revenue for state and local governments. ${ }^{1}$ At the same time, large metropolitan centers have been attracting labor and capital from adjoining states; many individuals now earn income from sources in states other than the one in which they reside. ${ }^{2}$ Consequently, as more and more jurisdictions adopt the personal income tax and assert their power to tax both resident and nonresident income-earners, ${ }^{3}$ the danger of multiple taxation will increase unless states exercise restraint in the use of their taxing power. ${ }^{4}$ It is the purpose of this Note to examine what efforts the states are making to relieve or eliminate this burden and to assess the degree of success they have been able to achieve.

\section{The Scope of State Taxing Power}

A state may tax the entire net income of residents regardless of its source, ${ }^{5}$ and it may tax nonresidents on income derived from sources within the state. ${ }^{6}$ Thirty-four states ${ }^{7}$ and the District of Columbia ${ }^{8}$ presently

1 See Hellerstein, Cases on State and Local Taxatron 527 (2d ed. 1961); Caruso, State Taxation of the Income of Nonresidents: A New Jersey Dilemma, 15 RuTGERS L. REv. 311-13 (1961).

2 See Caruso, supra note 1, at 313; Travis v. Yale \& Towne Mfg. Co., 252 U.S. $60,80-81$ (1920).

3 See Starr, Reciprocal and Retaliatory Legislation in the American States, 21 MrNn. L. Rev. 371, 401 (1937).

4 The term "power" is used in the sense of state power consistent with the United States Constitution. See Caruso, supra note 1, at 313-14.

5 New York ex rel. Cohn v. Graves, 300 U.S. 308 (1937) ; Lawrence v. State Tax Comm'n, 286 U.S. 276 (1932).

A state tax upon income is not an interference with interstate commerce merely because the income is derived from a source in another state. Colgate v. Harvey, 296 U.S. 404, 419 (1935).

6 Shaffer v. Carter, 252 U.S. 37, 52 (1920) ; Travis v. Yale \& Towne Mfg. Co., 252 U.S. $60,76(1920)$; see New York ex rel. Witney v. Graves, 299 U.S. 366 (1937).

7 Ala. Code tit. 51, § 373 (1958); Alaska Comp. Laws Ann. \$48-10-5 (Supp. 1958); Ariz. Rev. Stat. Alnn. \$ 43-102 (1956); Ark. Stat. ANn. \$ 84-2003 (Supp. 1961) ; Cal. Rev. \& Tax Code \$17041; Colo. Rev. Stat. Ann. \$138-1-2(1) (1953); Del. Code Ann. tit. 30, §1101 (1953); Ga. Code AnN. \$92-3112 (1961); Hawatr Rev. Laws § 121-3 (Supp. 1961); IdAHo Code ANN. § 63-3002 (Supp. 1961) ; IowA Code AnN. \$ 422.5 (Supp. 1962); Kan. Gen. Stat. Ann. \$ 79-3203(a) (Supp. 1961); Ky. Rev. Stat. \$141.020 (1962); La. Rev. Stat. Ann. \& 47:31 (Supp. 1962); Md. ANn. Code art. 81, $\$ 288$ (Supp. 1962); Mass. ANn. LAws ch. 62, $\S \S 5-5 A$ (Supp. 1962); MINN. Stat. AN'N. \$290.03(2) (1962); Miss. Code ANn. \$ 9220.03 (Supp. 1960); Mo. AnN. Stat. \$143.010 (Supp. 1962); Mont. Rev. Codes ANN. \$ 84-4902 (Supp. 1961); N.H. Rev. Stat. ANN. \$ 77:3 (1955); N.J. Rrv. Stat. $\$ 54: 8 A-3$ (Supp. 1962); N.M. Stat. AnN. \$72-15-1 (Supp. 1961); N.Y. TAX LAw $\S 601$ (a); N.C. Gen. Stat. §105-131 (1958); N.D. CEnT. Code \$\$ 57-38-02, -03 (1960); 'OkLA. Stat. AnN. tit. 68, \&876 (Supp. 1962); Ore. Rev. Stat. \$ 316.055 (1961); S.C. CoDE \&65-221 (1962); UTAF CODE ANN. \$ 59-14-2 (1953); VT. STAT. ANN. tit. 32, \$\$ 5641-42 (Supp. 1961); VA. CODE ANN. \$ 58-101 (Supp. 1962); W. VA. Code Atno. \$999 (50rr) (1961); Wis. Stat. ANn. §71-01 (Supp. 1963).

8 D.C. CODE ANN. § 47-1567 (1961). 
impose a tax on personal net income, ${ }^{9}$ and of these thirty-five jurisdictions, all but two-New Hampshire and the District of Columbia ${ }^{10}$-impose the tax on both residents and nonresidents. ${ }^{11}$ This broad power to tax both residents and nonresidents is based on the Supreme Court determination that the due process clause of the fourteenth amendment does not prohibit more than one state from taxing the same income so long as the income has a sufficient relation to the benefits and protections provided by each taxing state. ${ }^{12}$ The Court declined to extend the implication of the subsequently overruled "death transfer tax cases" that the Constitution prohibits multiple taxation. ${ }^{13}$ As a result, the Court avoided the necessity of determining which state would be allowed to tax income earned outside the state of residence, leaving to the states, acting either alone or in concert, the task of alleviating potential multiple tax burdens.

Three factors should especially impel the states to seek a solution to this problem. The financial hardship which multiple taxation could cause suggests that one taxpayer should not be subject to double taxation merely because he earns income outside his state of residence. Furthermore, multiple taxation will deter out-of-state employment and investment, thus immobilizing capital and labor with a consequent deleterious effect on both state and national economies. Finally, the solution of this problem challenges the states' capacity for cooperation among themselves, an essential element of a federal system.

\section{Specific Burdens and State Attempts at Alleviation}

\section{A. Classification Problems in the Taxation of "Residents" and "Nonresidents"}

Since states may tax the entire income of residents and the income of nonresidents that has its source within the taxing jurisdiction, ${ }^{14}$ the initial definitions of "resident" and "source of income" have a significant impact

9 Indiana imposes a tax on gross income. IND. ANN. STAT. \$64-2602 (1961).

10 See N.H. Rev. Stat. ANn. \&77:3 (1955). However, nonresidents who were residents of New Hampshire during a part of the preceding tax year must pay a tax pro tanto. Ibid.

Under the District of Columbia tax law, nonresidents are subject to an "Unincorporated Business" tax. See D.C. CODE ANN. \$ 47-1567 (1961).

11 See statutes cited notes 7-8 supra.

12 Guaranty Trust Co. v. Virginia, 305 U.S. 19 (1938); Shaffer v. Carter, 252 U.S. 37 (1920).

13 First Nat'l Bank v. Maine, 284 U.S. 312, 326 (1932) ; Baldwin v. Missouri, 281 U.S. 586 (1930) ; Farmers Loan \& Trust Co. v. Minnesota, 280 U.S. 204 (1930).

The "death transfer tax cases" were subsequently overruled. State Tax Comm'n v. Aldrich, 316 U.S. 174 (1942); see Curry v. McCanless, 307 U.S. 357 (1939).

For a discussion of the then prevailing doctrine that multi-state inheritance taxation was prohibited by the fourteenth amendment but multi-state income taxation was not and one writers' inability to reconcile the apparent inconsistency, see Starr, supra note 3, at 400; Rottschaefer, State Jurisdiction To Tax Income, 22 IowA L. REv. 292, 312 (1937) ; 21 MrNN. L. REv. 759 (1937).

14 See notes 5-6 supra and accompanying text. 
on ultimate tax burdens. Many states have so defined these terms as to achieve a minimal uniformity and thereby avoid multiple burdens. Other states have minimized definitional inconsistency by construction of their statutes or administrative practices.

\section{1. "Residents"}

Although a few states restrict the definition of "resident" to persons domiciled or legally resident ${ }^{15}$ therein during the taxable year, the majority extend the term to include persons maintaining a permanent place of abode within the state for some specified portion of the tax year. ${ }^{16}$ The purpose of the latter statutes is to tax the entire income of persons who enjoy the benefits and protections accorded by the state even though they may not be domiciliaries in the traditional common law sense. ${ }^{17}$

When an individual maintains living accommodations in more than one state or is domiciled in a jurisdiction other than the one in which he resides, the varying definitions of "residence" may aggravate the burden of multiple taxation. The following example illustrates both of these problems:

$\mathrm{T}$ was born and raised in the state of Mississippi. He is employed in the Mississippi branch of a nationwide corporation. The corporation transfers $T$ to its New York City headquarters to participate in a three-year training program after which he will be sent back to the Mississippi plant in an executive capacity. $T$ decides to rent a home in northern New Jersey within commuting distance of his New York City office. Finding himself working late at night and missing the last train to New Jersey, he leases an apartment in New York City, going to his New Jersey home only on weekends.

The Mississippi tax statute defines a "resident" as any person domiciled in the state or who maintains a legal or actual residence within the state. ${ }^{18}$ It defines a "nonresident" as any person whose domicile and place of abode are without the state. ${ }^{19}$

15 E.g., Ky. REv. STAT. $\$ 141.010(16)$ (1962); Mass. ANN. LAws Ch. 62, § 5A (a) (Supp. 1962); N.M. StAT. ANn. \$ 72-15-3(m) (1953); cf. MinN. Stat. ANN. \$290.01(7) (1962); MISS. CoDE ANN. \$9220.02(e) (1952); see Ness v. Comm'r, 279 Mass. 369, 181 N.E. 178 (1932); Feehan v. Tax Comm'r, 237 Mass. 169, 129 N.E. 292 (1921); Phillips v. South Carolina Tax Comm'n, 195 S.C. 472, 12 S.E.2d 13 (1940).

16 E.g., ARK. Stat. ANn. \$ 84-2002(9) (1947) (6 months); Colo. Rev. Stat. ANN. \&138-1-1(11) (1953) (6 months); DeL. CODE ANN. tit. 30, §1101 (1953) (7 months); GA. CODE ANN. \$ 92-3002(3) (1961) (183 days); LA. Rev. Stat. ANN. $\$ 47: 31$ (1) (1952) (6 months); MD. ANN. Code art. 81, \$279(i) (Supp. 1962) (6 months); N.Y. TAX LAW §605(a) (183 days); N.D. CENT. Cone § 57-38-01(10) (1960) (7 months).

171 CCH Cax. Tax REP. $\| 15-069$.

18 Miss. Code ANN. $\$ 9220.02$ (e) (1952).

19 MIss. Code AN'N. $\$ 9220.02(\mathrm{f})$ (1952). 
Under the common-law definition of domicile, ${ }^{20} \mathrm{~T}$ may still be a domiciliary of Mississippi and subject to that state's personal income tax on his entire net income. ${ }^{21}$ New York includes within its definition of "resident" any person who maintains a permanent place of abode in the state and spends more than 183 days of the taxable year there. ${ }^{22} \mathrm{~T}$ does spend more than the requisite number of days in New York, working and sleeping within the state at least five out of seven days each week. Whether or not $\mathrm{T}$ is taxable as a resident of that state, therefore, turns on whether his apartment in New York City can be said to be "a permanent place of abode"; if it is, T may find himself taxable as a resident of New York. ${ }^{23}$ Although New Jersey does not have a personal income tax act of general applicability, it has recently enacted a personal income tax provision applicable to residents ${ }^{24}$ earning income in New York. ${ }^{25} T$ may, therefore, be considered a "resident" of New Jersey for the purposes of that state's limited income tax provisions. ${ }^{26}$

Regardless of T's ultimate tax liability to each of these three states, the example illustrates the difficulty and uncertainty that faces an individual in his circumstances. Even if he is aware of the tax statutes of the three states and the possibility that he may be subject to one or more of them, the burden of informing himself of his tax liability is very great. Moreover, any authoritative determination will have to be obtained from the tax officials of those states.

20 Actual presence within the state coupled with an intent to remain indefinitely. E.g., Miller v. Commissioner, 240 Minn. 18, 59 N.W.2d 925 (1953).

21 Although $T$ is actually present in another state, he does not have an intent to remain indefinitely but has a present intention of returning to Mississippi within three years. Thus, there is substantial ground for saying that $T$ has not lost his Mississippi domiciliary status.

22 N.Y. TAX LAW $\$ 605$ (a) (2).

23 See New York Attorney General's Income Tax Letter No. 44, Mar. 25, 1921, $1 \mathrm{CCH}$ N.Y. TAX REP. T 15-075.27. A prior New York tax regulation stated:
A permanent place of abode is understood to mean a dwelling place per- manently maintained by the taxpayer, and will generally include a dwelling place owned or leased by his or her spouse. It is not necessary that the individual be the owner. $A$ person domiciled outside this state who main- tains a home or apartment in New York, whether or not he or she uses such place of abode, is to be considered a resident if he or she spends an aggregate of more than 183 days of the taxable year within the State. On the other hand, a person who comes into the State to accomplish a particular object, intending to remain only for that temporary period, who establishes a place of abode and spends more than 183 days of the taxable year within the State, is not to be considered as maintaining a permanent abode within the State unless there is evidence to show an intent to make the place of abode so established a permanent one.

1 CCH N.Y. TAX REP. $\| 15-081$. (Emphasis added.)

24 N.J. Rev. Stat. $\$ 54: 8 \mathrm{~A}-3$ (Supp. 1962) (permanent place of abode for 183 days of the tax year).

25 N.J. REv. STAT. \$54:8A-2 (Supp. 1962); see notes 80-90 infra and accompanying text.

26 This, of course, turns upon whether T's home in New Jersey is "a permanent place of abode." See note 24 supra. 
Many taxing jurisdictions, aware of the burden created by divergent definitions of "resident," have taken various steps to alleviate its impact. ${ }^{27}$ A few states exclude a domiciliary from the category of "resident" if he maintains no permanent place of abode within the state, does maintain permanent living quarters outside the state, and spends less than a specified number of days within the state during the tax year. ${ }^{28}$ In addition, several states allow an individual to show that he has only temporary or transitory contacts with the state, thereby rebutting any presumption of residence raised by his spending more than a stated portion of the tax year within the jurisdiction. ${ }^{29}$

Another provision expressly enacted to avoid double taxation caused by inconsistent definition allows a person changing his residence during any part of the taxable year to report and pay a tax only for that portion of the year in which he was a resident and to comply with the nonresident tax provisions for the rest of the year. ${ }^{30}$ This provision appears to be a matter of legislative grace since a state apparently can tax the entire net income of a resident on the tax day, regardless of how short the time he has been in the taxing state. ${ }^{31}$

One state, Colorado, permits a person establishing a temporary residence within the state to apply for a certificate of nonresidence. ${ }^{32}$ A holder of this certificate is presumed not to be a resident of Colorado, regardless of the length of time he may spend in the state within the tax year.33 A person coming to Colorado for a temporary or transitory purpose who stays for more than six months is presumed to be a resident unless he holds such

27 Because of its status as the seat of national government, the District of Columbia has several provisions designed to alleviate dual taxation of government officers and employees. The District tax code defines "resident" to exclude all elective federal government officers and certain classes of appointees and employees not domiciled in the District. D.C. CODE ANN. \$47-1551c(s) (1961). See generally District of Columbia v. Murphy, 314 U.S. 441 (1941). The District also allows a tax credit to residents of the District for income taxes paid to the state of domicile. D.C. CODE ANN. \$47-1567d(a) (1961). The latter provision eliminates the possibility of double taxation, while the former may, in the case of domiciliaries of nontaxing states, relieve the taxpayer of any liability.

28 E.g., Dex. Code ANN. tit. 30, \$1101 (Supp. 1962); N.Y. TAX LAW §605(a); cf. Ariz. Rev. Stat. Ann. \$43-101 (p) (1956).

29 E.g.y Ariz. Rev. Stat. Ann. \$ 43-101(r) (1956); N.C. Gen. Stat. § $105-$ 132(13) (1958); Ore. Rev. Stat. §316-010(14) (1961); cf. Ga. Code AnN. \$ $92-$ 3002 (i) (4) (1961).

30 E.g., Ga. Code Ann. \$ 92-3002(i) (4) (1961); Md. Ann. Code art. 81, §279(i) (Supp. 1962); N.C. GEN. STAT. \$105-132(13) (1958); VA. Code ANN. \$\$ 58-77 (1950); see 22 Minn. L. Rev. 746 (1938). But see N.M. Stat. Ann. \$72-15-3(m) (1953).

31 In fact, several states that make no provision for change of residential status appear to levy a tax on entire net income if the taxpayer at any time during the taxable year was a "resident" of the state or is a "resident" on tax day. See, e.g., Ala. Code tit. 51, §373 (1958); Iowa Code ANn. \$ 422.4 (1949), as amended, IowA Code Ann. \$ 422.4 (Supp. 1962).

32 Colo. Rev. Stat. Ann. §138-1-52 (1953).

33 Colo. Rev. Stat. Ann. \$138-1-57 (1953). The statute provides for annual renewal of the certificate, upon filing a new affidavit. Colo. REv. Stat. ANN. §1381-55 (1953). 
a certificate. ${ }^{34}$ Only income earned from sources within the state must be reported by a certificate holder. ${ }^{35}$

Although in sum the burden imposed by differing definitions of "resident" may be slight, ${ }^{36}$ the consequences to individual taxpayers such as the one in the example may be oppressive. Nor is there apparently any strong countervailing state interest in not providing relief for these taxpayers beyond a possible desire to tax persons who maintain residences in more than one state. Since the revenue loss to the states resulting from elimination of this double taxation would be slight and conformity of definition would facilitate tax administration, closer approximation to uniformity should be attempted in order to alleviate the taxpayer's burden of determining to which state or states he must pay tax.

\section{2. "Nonresidents"}

A state may tax nonresidents on income derived from sources within the state. ${ }^{37}$ The definitional difficulty here centers around "sources within the state." The problem is illustrated by the case of a corporate executive or salesman who has offices in one state and is paid there, but who performs the services for which he is compensated in other states. A number of cases have held that in this situation a state may tax compensation for services not required to be performed outside of the taxing jurisdiction. ${ }^{38}$ Thus a corporate executive who prefers to do most of his work at his home in another state may be taxed by the state in which his office is located. On the other hand, no state appears to tax income earned for services required to be performed outside the taxing state, although it may have the constitutional power to do so. ${ }^{39}$ In addition, although the same income could also be taxed by the state in which the services were actually rendered, the great difficulty in allocating income earned for services rendered in several states may preclude the exercise of this taxing power. ${ }^{40}$ Certainly the revenue gained by such an attempt would not outweigh the administrative burden of collection and the taxpayer inconvenience that it would cause.

\section{B. Double Taxation of the Interstate Commuter}

Whenever an individual works in a state other than his residence, he will be potentially subject to double taxation if both states elect to exercise the full measure of their taxing power. States have, however, employed a number of devices to alleviate this potential burden.

34 Colo. Rev. Stat. Ann. § 138-1-1(11) (1953).

35 Colo. Rev. Stat. ANN. § 138-1-57 (1953).

36 In most instances the status of a taxpayer will be clear since he will not have multiple residential contacts but only multiple income producing contacts.

37 See note 6 supra and accompanying text.

38 See, e.g., Morehouse v. Murphy, 10 App. Div. 2d 764, 197 N.Y.S.2d 763, appeal dismissed, 8 N.Y.2d 932, 168 N.E.2d 840, 204 N.Y.S.2d 170 (1960); Burke v. Bragalini, 10 App. Div. 2d 654, 196 N.Y.S.2d 391 (1960).

39 See generally Hellerstein, Cases on State and Local Taxation 546-48 (2d ed. 1961).

$40 I d$. at $547-48$. 


\section{Abstention}

Two jurisdictions, New Hampshire and the District of Columbia, do not tax nonresident income at all, ${ }^{41}$ and several states, motivated to a large degree by problems of administrability and to a lesser extent by considerations of multiple taxation, do not attempt to tax all income of nonresidents derived from sources within the state. ${ }^{42}$ The usual statutory provision restricts taxation of nonresidents to so much of their entire income as is attributable to an interest in real or tangible personal property located within the state or to carrying on a business, profession, trade, or occupation within the state's borders. ${ }^{43}$ Income from interest-bearing obligations and from corporate dividends is excluded from the nonresidents' taxable income unless it is connected with business, trade, or occupational activity within the state. ${ }^{44}$ The states have been less willing, however, to forego taxation of the entire net income of residents. ${ }^{45}$ But several states do exempt from taxable income of residents that portion which is derived from the conduct of a business without the state. ${ }^{48}$

A few states make provision in their tax acts for the complete exemption of nonresidents from any tax on income if a similar exemption is granted to their residents. ${ }^{47}$ Maryland ${ }^{48}$ has such a reciprocal clause in its statute; however it restricts its operation to salary, wages, or other compensation received for personal services.99 Since these nonresident exemptions operate in only a very few cases, their beneficial effect on the reduction of potential double taxation is slight. And, although the limited exclusions for residents do eliminate multiple taxation on the excluded income $^{50}$ in the aggregate they effect little reduction of potential multistate taxation.

The reason for the limited use of exemptions is probably their lack of flexibility; exemptions which do not correspond to taxes imposed by other states, for example, operate to exclude income even when a taxpayer is not subject to double taxation. States are justifiably unwilling to permit this taxpayer bonanza.

41 See note 10 supra and accompanying text.

42 See, e.g., Ark. Stat. AnN. \$ 84-2020(1) (1960); D.C. Code Ann. \$47-1567 (1961) ; OkLA. Stat. tit. 68, §876(a) (Supp. 1962); S.C. Code §65-221 (1962).

43 E.g., ARK. Stat. ANn. \$84-2003(c) (1960); Miss. Code Ann. \$ 9220.03(2) (Supp. 1960); N.D. Cent. Code \$ 57-38-03 (1960); VA. Code ANN. \$ 58-101 (Supp. 1962).

44 E.g., Iowa Code Ann. $\$ 422.8(2)$ (Supp. 1962) ; Mrss. Code ANN. §922012 (1) (a) (Supp. 1960); UTAF CODE ANN. \$59-14-68(1) (c) (Supp. 1961).

45 But see Alaska Conp. Laws ANN. \$48-10-5 (Supp. 1959) (income from sources within the state); OkLA. STAT. tit. 68, $\$ 876$ (a) (Supp. 1962) (income from personal services only).

46 E.g., Minn. Stat. Ann. \$290.19 (1962); N.D. Cent. Code §57-38-04(4) (1960); Wis. Stat. ANN. $\$ 71.07$ (1957).

47 E.g., Ky. Rev. Stat. $\$ 141.070(3)$ (1962); Wis. Stat. Ann. $\$ 71.07(1)$ (Supp. 1963).

48 MD. AnN. CoDE art. 81, §291 (1957).

49 Ibid.; accord, Wis. Stat. AnN. \$71.03(2) (f) (Sudd. 1963).

50 See note 51 infra. 


\section{Credits}

The most important concession made by the states to alleviate multiple taxation is the allowance of credits for income taxes paid to other jurisdictions.51 Most of the states afford some type of credit to resident taxpayers ${ }^{52}$ and several extend a credit to nonresidents if the home state of the nonresident reciprocates. ${ }^{53}$

\section{a. Operation and Limitations}

A credit provision permits a qualifying taxpayer to subtract from the tax owed the credit state an amount equivalent to some portion of the tax paid to a foreign state. ${ }^{54}$ In order to prevent unnecessary diminution of their revenue ${ }^{55}$ a majority of credit states place statutory limitations ${ }^{56}$ on the amount of the foreign state tax that a qualifying taxpayer is permitted to credit. The purposes of these limitations are twofold: to insure that relief is granted only when the same items of income are subject to double taxation,,$^{57}$ and to reduce the reflection in the credit of a higher rate of

51 No study of a state's allowance or denial of credits is complete without consideration of the income it actually taxes. Some states exempt certain types of income from taxation, instead of granting credits. Hellerstein, Cases on STATE aNd Locai Taxation 561 (2d ed. 1961).

E2 Ala. Code tit. 51, \$390 (1958); ARIz. Rev. Stat. ANN. \$43-128 (1956); ARK. Stat. ANn. \$ 84-2017 (1960); Car. Rev. \& TAX Code \$ 18001; Colo. Rev. Stat. ANN. \$138-1-41 (1953); DEe. CODE ANN. tit. 30, \$1120 (Supp. 1962); D.C. CoDE ANN. \$ 47-1567d (1961); GA. CoDE ANN. \$.92-3111 (1961); HAwaII Rev. LAws \$121-12 (Supp. 1961); IDAHO CODE ANN. \$63-3029 (a) (Supp. 1961); Iowa CODE ANN. \$ 422.8 (Supp. 1962); KAN. GeN. STAT. ANN. \$ 79-3232 (Supp. 1961); KY. Rev. Stat. \$141.070 (1960); La. Rev. Stat. Ann. \$47:33 (Supp. 1961) ; Mp. Ann. Code art. 81, $\$ 290$ (1957); Mass. AnN. IAws ch. 62, \$6A (Supp. 1962); MinN. Stat. Ann. \$290.081 (1962); Miss. Code AnN. \$9220-38 (Supp. 1960); Mo. ANN. Stat. \$143.160.1 (5) (Supp. 1962) ; Mont. REv. Codes ANN. \$ 84-4937 (Supp. 1961); N.J. Rev. Stat. \$ 54:8A-16 (Supp. 1962); N.M. STAT. ANN. \$ 72-15-25 (Supp. 1959) ; N.Y. Tax Law $\$ 620$ (a); N.C. Gen. Stat. \$ 105-151(a) (1958); N.D. Cent. Code § 57-38-04(2) (1960); OKLA. STAT. tit. 68, \& 876(a) (Supp. 1962); Ore. REv. STAT. \$316.475 (1961); SC. CODE \$ 65-340 (1962); UTAR CODE ANN. \$ 59-14-70 (Supp. 1961); VT. Stat. ANN. tit. 32, \$5646 (1959); VA. Code ANN. \$ 58-103 (Supp. 1962); W. VA. Code ANN. \$999(50iii) (1961); WIs. STAT. ANN. \$71.05(5) (Supp. 1963).

53 Cal. Rev. \& Tax Code \$18002; Dex. Code Ann. tit. 30, \$1120 (Supp. 1962); IDAHo CoDe ANN. \$ 63-3029 (b) (Supp. 1961); KY. Rev. Stat. \$141.070(2) (1960); MD. ANN. Code art. 81, \$291 (a) (1957); N.C. GEN. STAT. \$105-151(d) (1958); VT. Stat. ANN. tit. 32, \&5647(a) (1959); VA. Code ANN. \& 58-104 (Supp. 1962); W. VA. CODE ANN. \$999(50cccc) (1961).

Arizona allows the nonresident credit regardless of reciprocation. See ArIz. Rev. Stat. ANN. \$ 43-128(b) (1956).

54 For example, if the amount of tax that the taxpayer would have to pay in the absence of credit is $\$ 250$ and the taxpayer is entitled to a tax credit of $\$ 50$ under applicable law, then the $\$ 50$ is subtracted from the $\$ 250$ leaving $\$ 200$ payable.

55 The possible diminution can be illustrated as follows: A resident taxpayer has gross income of $\$ 10,000, \$ 4,000$ of which was earned outside the state. The credit state's tax on the $\$ 10,000$ is $\$ 500$. Taxpayer has paid a tax on the $\$ 4,000$ to a foreign state amounting to $\$ 300$. Had the credit state not elected to tax him on the $\$ 4,000$ but restricted its tax to $\$ 6,000$, it would have realized $\$ 250$. If it now allows taxpayer a credit for the full $\$ 300$ paid to the foreign state, it will receive from him only $\$ 200$ ( $\$ 500$ minus $\$ 300)$. Thus, the credit state would maximize its revenue by not taxing him on income earned without the state.

(Supp. 1962).

57 This is consistent with the general policy that the states will relieve a taxpayer only from more than one tax on the same income. 
foreign taxation than that imposed by the credit state..$^{58}$ Thus, although the states recognize the double taxation problem, ${ }^{59}$ most-but not allallow tax credits only to alleviate the burden created by their own tax policy; they do not attempt to relieve the taxpayer from different and conflicting policies of sister states. A variety of statutory formulae are employed to achieve this end.

Since states taxing nonresident income need not be concerned with allowing credit for higher rates of foreign taxation-the nonresident credit, of course, cannot exceed the amount of tax that would be due the credit state, at its tax rates, on the nonresident income-, the only limitations found in nonresident credit provisions are directed toward insuring that relief is granted only in cases of double taxation. ${ }^{60}$

In order to ensure that a credit is not taken for taxes paid on nonresident income taxed by the foreign state but not by the credit state, statutes provide that the nonresident credit shall be computed as that percentage of the foreign tax equal to the ratio of income taxed by both states to total income taxed by the foreign state. ${ }^{61}$ In those instances in which the credit state taxes income not taxed by the foreign state, the credit may be statutorily limited to that percentage of the credit state tax equal to the ratio of nonresident income taxed by both states to nonresident income taxed by the credit state. ${ }^{62}$

Since states allowing resident credits cannot eliminate the crediting of higher foreign rates of taxation by the device of disallowing credit on items of income not doubly taxed, the limitations imposed on resident credits are more varied. They are usually restricted to the lesser of some of the following calculations: (1) the amount of the foreign tax actually paid; ${ }^{63}$ (2) a percentage of the credit state tax equal to the ratio of income taxed by both states to the entire income taxed by the credit state; ${ }^{64}$ (3) the reduction of tax that would occur if the foreign income were excluded

58 See Starr, Reciprocal and Retaliatory Legislation in the American States, 21 Minn. L. REv. 371, $402-03$ (1937); see note 55 supra.

59 See, e.g., GA. Cone ANs. \$92-3329b (1961) ; Phillips v. South Carolina Tax Comm'n, 195 S.C. 472,12 S.E.2d 13 (1940).

60 See, e.g., Cad. Rev. \& TAX CodE § 18002; KY. Rev. Stat. \$141.070(2) (1960); Vt. Stat. AnN. tit. 32, §5647(a) (1959); VA. Code AnN. \$58-104 (Supp. 1962).

61 See $i b i d$.

62 See Ariz. Rev. Stat. Ans. \$43-128(b) (3) (1956) ; Cal. Rev. \& Tax Code $\S 18002$ (d) ; cf. VA. CODE ANN. \$ 58-104 (Supp. 1962)

63 E.g., Idaho Code AnN. \$63-3029(a) (Supp. 1961); N.C. Gen. Stat. \$105151 (a) (3) (1958); ORE. REv. STAt. \$ 316.475 (c) (1961).

64 E.g., Arrz. Rev. Stat. AnN. \$ 43-128(a) (2) (1956) ; Cat. Rev. \& Tax Code $\S 18001$ (c); Mass. Ans. Laws ch. 62, §6A(c) (2) (Supp. 1962); Mo. Ann. Stat. $\$ 143.160$ (5) (a) (Supp. 1962); N.C. Gen. Stat. \$105-151(a) (3) (1958); OrE. Rev. STAT. \$ 316.475 (c) (1961).

The following example will illustrate the operation of this clause: Taxpayer has gross income subject to tax by residence state of $\$ 10,000, \$ 4,000$ of which was earned outside the state and taxed by the source state. The tax otherwise payable on the $\$ 10,000$ to the credit state is $\$ 1,000$. The maximum credit for taxes paid to the foreign state would be $\%$ of $\$ 1,000$ or $\$ 400$ even if the actual tax paid was greater than $\$ 400$. 
altogether from the credit state's tax base; ${ }^{65}$ (4) the amount of tax that would be payable to the credit state on an amount of income equal to that taxed by the foreign state. ${ }^{68}$ Although the amount of the allowable credit will depend on which clause or combination of clauses a particular state employs, ${ }^{87}$ any combination will to some extent eliminate the effects of higher rates of taxation and differing progressive structures. ${ }^{68}$

65 E.g., Ky. Rev. Stat. $\$ 141.070(1)$ (1960); Md. ANn. Code art. 81, $\$ 290$ (1957); Minn. Stat. AnN. \$290.081(2) (1962); W. VA. Code AnN. §999(50iii) (1961) ; cf. N.D. CENT. CODE \& 57-38-04(2) (Supp. 1961).

Taxpayer has gross income subject to tax by credit state of $\$ 10,000, \$ 4,000$ of which was earned and taxed outside the state. The tax otherwise payable on $\$ 10,000$ to the credit state is $\$ 1,000$. If the amount earned in the foreign state were excluded from gross income reported to the credit state, taxpayer would be liable for a tax of $\$ 500$ on a reported gross income of $\$ 6,000$. In computing the maximum credit allowable, taxpayer would subtract $\$ 500$ from $\$ 1,000$ giving him an upper limit of $\$ 500$ even if the foreign tax were greater.

66 E.g., AlA. Code tit. 51, \$390(c) (1958); ARK. Stat. ANN. \$ 84-2017 (1960); GA. Code ANn. \$ 92-3111 (1961); Towa CODE ANN. \$ 422.8(1) (Supp. 1962); Miss. Code ANN. \$ 9220-38(2) (Supp. 1960) ; OKLA. Stat. tit. 68, §876 (Supp. 1962).

Taxpayer had $\$ 4,000$ of income that was earned and taxed within a foreign state. In order to compute the maximum credit under this clause, taxpayer would subtract the allowable deductions and exemptions under the credit state's tax law and compute a tax on the taxable income thus determined at the tax rates imposed by the credit state on that amount of taxable income.

67 Taxpayer has a gross income of $\$ 10,000$ for credit state tax purposes, $\$ 4,000$ of which was earned in and taxed by a foreign state. The tax otherwise payable to the credit state without the subtraction of allowable credit is $\$ 1,000$ and the actual tax paid to the foreign state was $\$ 600$. The foreign state's tax structure is more steeply progressive than is the tax structure of the credit state. On $\$ 4,000$ gross income after deductions and exemptions the credit state's tax would be $\$ 250$ and the foreign state's tax is $\$ 600$. The credit state's tax on $\$ 6,000$ of gross income after deductions would be $\$ 425$. Applying the first limitation, the actual tax paid to the foreign state is $\$ 600$. If the second clause were employed by the state as a limiting factor, the maximum credit on the facts stipulated would be $\$ 400$ ( $\%$ of $\$ 1,000$ ). If the third limitation were used, $\$ 575$ would be the maximum credit permitted $(\$ 1,000$ minus $\$ 425$ ). If the fourth clause were the applicable limitation, the credit allowed would be only $\$ 250$ (credit state's tax on $\$ 4,000$ ).

68 In the illustrative example in note 67 supra, it was posited that the foreign state had a higher effective rate of taxation at any given income level because it had a more progressive tax structure. Although the actual amount of foreign income tax paid was $\$ 600$, taxpayer would not be allowed a $\$ 600$ credit under any limitation clause. Under the third limitation clause, he would be entitled to the greatest amount of credit, $\$ 575$. A state adopting this clause would be satisfied if it received in taxes from the taxpayer the same amount that it would have received had it not taxed him on his foreign income. In doing this the credit state not only allows taxpayer to credit an amount equal to what the credit state's tax would have been on the outside income computed at the base rate but it also permits him the benefit of the increment in $\operatorname{tax}$ revenue that it would have derived if that portion of income were taxed at the progressive rate. When the second limitation is employed, the maximum credit allowable is reduced to $\$ 400$. Since the limitation is computed by taking a proportion of the tax otherwise payable to the credit state and the tax otherwise payable is computed at progressive rates, the credit state permits the taxpayer to credit not only an amount equal to what the credit state's tax would have been on the same amount of income upon which he paid his foreign tax at the base rate levied by the credit state, but it also allows him to credit the same proportion of the increment in tax that it would have received solely from the progressive rate structure. This position is midway between the second limitation clause and the fourth. By employing the fourth clause, the state permits the taxpayer a credit limited to the exact amount that the credit state would have taxed on a like quantity of income that was taxed by the foreign state. This method will completely eliminate from the credit allowable not only any amount caused by higher tax rates imposed by the foreign state, but it will also remove from the credit any amount resulting from its own progressive rates. 
In addition to limiting the creditable amount, states have established certain prerequisites to the taking of a credit. One requirement applicable only to residents is that taxes have been paid to another jurisdiction exercising a nonresident taxing power. ${ }^{69}$ If a resident is liable to a foreign state as a resident taxpayer, the credit state will allow him no credit for taxes paid on that portion of income that would not be taxable to a nonresident of the foreign state. The most onerous qualification on the allowance of credit to nonresidents is that the state of residence grant a substantially similar credit to residents of the credit state or exempt from taxation their income from sources within that state. ${ }^{70}$ Usually, a credit may be taken only for taxes paid to another state of the Union, including the District of Columbia and occasionally United States territories. ${ }^{71}$ Taxes paid to a foreign country are sometimes credited; ${ }^{72}$ however, a state will rarely allow a credit for income taxes paid to a political subdivision of another state. ${ }^{73}$ When the credit state allows a deduction for foreign income taxes, the taxpayer must elect the deduction or the credit, ${ }^{74}$ but cannot have the advantages of both. Generally the credit may be taken only in the year in which tax is actually paid ${ }^{75}$ unless the taxpayer makes his return on an accrual basis.

To prevent a taxpayer from taking more than one credit for the same income, credit provisions generally provide that a resident taxpayer is ineligible for a resident credit if he qualified for a foreign state's nonresident credit. $^{76}$ This limitation is designed to apply when the credit state and the foreign state have reciprocal nonresident credit statutes. Each of the states will grant a credit to the residents of the other, but deny a credit to its own residents who are eligible for the nonresident credit of the other. In addition, nonresident credits are unavailable to taxpayers who take credits in their state of residence. ${ }^{77}$ Nonresidents who reside in states that do not tax personal income are denied a credit for the obvious reason that they are not doubly taxed.

69 E.g., Cal. Rev. \& Tax Code $\$ 18001$ (a); La. Rev. Stat. AnN. \$47:33 (Supp. 1962); N.C. Gen. Stat. §105-151(a) (1) (1958); Ore. Rev. Stat. § 316.475 (a) (1961).

70 See note 53 supra.

71 E.g., N.D. Cent. Code Ann. \$57-38-04(2) (Supp. 1961); Utaf Code Ann. $\S 59-14-70(1)$ (1953).

72 See Mass. Ans. Laws ch. 62, $\S 6 \mathrm{~A}$ (Supp. 1962) (credit for taxes paid Canada).

73 E.g., DeL. Code Ans. tit. 30, $\$ 1120$ (Supp. 1962); N.Y. TAX LAW $\S 620$ (a).

74 E.g., Dex. Code Anv. tit. 30, 1120 (Supp. 1962); La. Rev. Stat. Ann. $\S 47: 33$ (3) (Supp. 1962).

75 E.g., Ala. Code tit. 51, $\$ 390$ (1958); N.D. CENT. Code $\$ 57-38-04$ (2) (Supp. 1961). But $c f$. N.Y. TAX LAW $\S 620$ (a).

76 E.g., CaL. REv. \& TAX CODE $\$ 18001$ (b); Ore. Rev. Stat. \$316.475(1) (b) (1961); W. Va. Code AnN. §999(50iii) (c) (1961).

77 E.g., Ariz. Rev. Stat. AnN. §43-128(b) (1) (1956) ; Cal. Rev. \& Tax Code $\S 18002(\mathrm{~b})$. 


\section{b. State Attitudes Toward Credits}

There is currently a discernible trend toward the elimination of the reciprocal nonresident credits in favor of affording only resident credits. ${ }^{78}$ Only about one-third of the taxing states still provide for a nonresident credit, $^{79}$ and even they restrict its benefits to persons who both reside in the state and are taxed as nonresidents. The decision whether to adopt or retain a nonresident tax credit may be influenced by state self-interest. If a state can anticipate more revenue from nonresidents earning income within its borders than it would lose by waiving its claim to tax income earned without the state by its residents, maximization of revenue can best be achieved by the adoption of a resident tax credit only. On the other hand, if a state is reasonably sure that nonresidents earn less within its territory than its residents earn without, it should enact both resident and reciprocal nonresident credits, foregoing some nonresident revenue in order to retain tax revenue from residents on income earned outside the state whenever the foreign state allows nonresident credit. On this theory, states which attract out-of-state labor and capital should abandon nonresident credits while jurisdictions which export labor and capital should retain them.

\section{c. New York-New Jersey Example}

Recent events in New York illustrate the possibility of employing tax credits to implement protective legislation against sister states. New York City is the hub of employment for many individuals living in neighboring New Jersey and Connecticut. ${ }^{80}$ New York taxed both residents and nonresidents but granted a nonresident reciprocal credit. ${ }^{81}$ Since New Jersey and Connecticut imposed no personal income tax, their residents were not entitled to any credit against New York taxes. ${ }^{82}$ New Jersey, although not desiring to enact an overall income tax, considered possible means of diverting to itself the tax revenue paid by its residents to New York. ${ }^{83}$ It attempted to take advantage of New York's reciprocal nonresident credit by enacting an income tax restricted to its residents commuting to New York and New York residents commuting to New Jersey. ${ }^{84} \mathrm{By}$ allowing a nonresident credit, New Jersey contemplated that New York would afford New Jersey residents a similar credit, thereby diverting New Jersey

78 See Iowa CoDe ANw. $\S \S 422.8(1)$-(2) (Supp. 1962); 1 CCH N.Y. TAX REP. II 15-335. Compare Mont. Rev. Codes ANN. \$ 84-4937 (1956), with Mont. Rev. CODES ANN. \$ 84-4937 (Supp. 1961).

70 See note 53 supra.

${ }^{80}$ See Travis v. Yale \& Towne Mfg. Co., 252 U.S. 60, 80-81 (1920), in which the Court took judicial notice of this fact.

811 CCH N.Y. TAX REP. II 15-335.

82 Ibid.; see Hellerstein, Cases on State and Local Taxation 548 (2d ed. 1961) ; Caruso, State Taxation of the Income of Nonresidents: $A$ New Jersey Dilemma, 15 Rutgers L. REv. 311, 316 (1961).

831 CCH N.J. TAX REP. $\pi 15-003$.

841 CCH N.J. TAX REP. II 15-201; see Caruso, supra note 82, at 320-24. 
resident tax revenue to New Jersey. ${ }^{85}$ New York, however, responded by repealing its nonresident credit $^{86}$ allowing only a resident credit. ${ }^{87}$ New Jersey residents were thus confronted with the possibility of double taxation on their New York income, and New Jersey was forced to amend its act to allow a resident credit for taxes paid to New York.88 The amendment completely reversed the original New Jersey scheme-New York residents earning income within New Jersey now pay a tax to that state and receive a resident credit against their New York tax, and New Jersey residents are taxed by New York on New York income but are not taxed by New Jersey. ${ }^{89}$

By New York's elimination of the nonresident credit, New Jersey was deprived of the larger revenue that it could have derived from its own residents and was left only with revenue collected from New York residents. Any action by New Jersey would have decreased New York's tax revenue; however, New York's response minimized the loss by recouping the larger nonresident revenue at the expense of abandoning the smaller revenue from its residents working in New Jersey.

This example cogently demonstrates the interaction between a state's interest in maximizing its revenue and its interest in protecting its citizens from double taxation. It is significant that neither New York nor New Jersey pursued the policy of maximization of revenue at the expense of subjecting their residents to double taxation. New Jersey, in fact, even relieved its residents earning income in New York of the nuisance of filing a return and then claiming the nonresident credit. ${ }^{90}$

\section{d. Effect of Credits on Multiple Taxation}

Although a credit provision does not eliminate the burden of multiple administration, reporting, and compliance, ${ }^{91}$ it does alleviate the most inequitable burden caused by multi-state taxation-two complete taxes on the same income. The taxpayer subject to taxation by more than one state pays less tax when one of the states allows a credit than could constitutionally be demanded. Admittedly, the tax credit cannot of itself remedy all inequities wrought by the system, but it is a noble concession when viewed as an act of legislative grace by the credit state.

85 See 1 CCH N.J. TAX REP. \ 15-301.

801 CCH N.Y. TAX REP. $\mid 13-335$.

87 N.Y. TAX. LAW. $\$ 620$.

$881 \mathrm{CCH}$ N.J. TAX REP. $\| 15-003$.

891 CCH N.J. TAX REP. $\| 15-201$.

901 CCH N.J. TAX REP. II 18-305.

91 Even if a taxpayer is allowed a tax credit from either the resident or nonresident taxing state, and is thereby relieved of two complete taxes on his income, the taxpayer must nonetheless file income tax returns to both states. Tax officials are required to spend time on his return even though he may ultimately be liable for no tax. See Caruso, supra note 82, at 319. 


\section{Personal Deductions and Exemptions}

Another device that sometimes alleviates multiple taxation is the allowance of generous personal exemptions and deductions. In strict compliance with the holding of Travis v. Yale \& Towne Mfg. Co., ${ }^{92}$ all of the taxing jurisdictions allow nonresidents personal exemptions.93 However, many states have interpreted Travis to require only that they afford a nonresident a partial deduction based on the proportion of the nonresident's total income earned within the state. ${ }^{94}$ A few states permit a nonresident to take the full personal exemption, even though only a fraction of his entire income is subject to taxation. ${ }^{95}$ When a full personal exemption is taken, the effect of double taxation is diminished; the degree of diminution depends on the ratio of income taxed by the state to entire income.

Generally, nonresidents are allowed itemized deductions only to the extent that the deductions are associated with income taxable by the state ${ }^{86}$ expenses such as real estate taxes, mortgage interest, and medical expenses which are unrelated to the production of income are not deductible. $^{97}$ If the taxpayer's home state imposes a personal income tax, he will probably deduct these items when reporting his income to that state. ${ }^{98}$ However when the state of residence does not tax personal income, the nonresident may find himself paying more tax to the foreign state than its residents who have the same amount and type of income. ${ }^{99}$ A few states grant nonresidents selected deductions not associated with the production of income within the state. ${ }^{100}$ The allowance of these deductions offers some relief from burdensome taxation.

\section{Administrative Relief From the Burdens of Multiple Taxation}

Many state tax authorities administer their tax statutes in such a way as to minimize or reduce the burden of multiple taxation. This is most

92252 U.S. 60 (1920). The Court held that insofar as New York allowed its citizens personal exemptions which it did not allow New Jersey and Connecticut residents, it violated the privileges and immunities clause. Id. at 80 .

${ }^{83}$ See, e.g., N.C. Gen. Stat. § 105-149 (1958) ; Mont. Rev. Codes AnN. § 84-4910 (Supp. 1961).

94 See, e.g., Ala. Code tit. 51, § 388 (Supp. 1961) ; ARK. STAt. AnN. § 84-2020(2) (1960); Mont. Rev. Codes ANN. \$84-4910(i) (Supp. 1961); VA. Code ANN. § 58-98(d) (1959).

95 See, e.g., N.J. Rev. Stat. §54:8A-10 (Supp. 1962) ; N.Y. Tax Law \$636;

W. VA. Code ANN. $\$ 999$ (50yyy) (1961); HelzersteIn, op. cit. supra note 82, at 548 .

96 See, e.g., LA. Rev. Stat. AnN. $\$ 47.76$ (1952) ; Mont. Rev. Codes AnN. $\$ 84-4907$ (1956); N.C. GEN. STAt. \$105-147(18) (Supp. 1961); VA. Code ANN. \$58-82 (Supp. 1962). However, many of these states allow a nonresident a standard deduction similar to that offered residents.

97 Compare Hellerstern, op. cit. supra note 82, at 548.

98 Compare ibid.

99 Compare ibid.

100 See, e.g. GA. Code ANn. \$92-3112(d) (1961); Minn. Stat. ANN. \$290.18(2) (1962); N.J. Rev. Stat. 54:8A-37 (Supp. 1962); N.Y. TAx LAW \& 635. 
often achieved by an administrative disinclination to interpret the taxing statutes to the constitutional limit.101 When the taxpayer is entitled to a tax credit, ${ }^{102}$ many statutes have explicit provisions permitting cooperation with the taxing officials of other states to eliminate all or a portion of income withholding that would otherwise be required. The express purpose of this legislation is "the relief of such taxpayer . . . from the multiple burden imposed by the operation of several current income tax payment laws." 103 The states attempt to alleviate the burden of having income withheld by two or more states when the taxpayer will ultimately be liable only for a fraction of the total withheld.

\section{Effectiveness of State Efforts}

It can be seen from the foregoing analysis of the characteristics of state personal income taxation that the taxing jurisdictions are aware of possible multiple taxation and have taken steps to alleviate the problem. No definitive conclusions about the extent of their success can be formed, however, without an examination of the actual operation of the tax structures.

\section{Regional Examples of Multi-State Taxation AND EFforts at Alleviation}

Since multi-state taxation generally arises out of the interaction of the tax laws of two or three neighboring states, any attempt to evaluate the burden of multiple taxation must include an examination of the practical application and effects of multiple taxation in specific situations. Three examples of the interaction of the tax laws of contiguous states follow.

\section{A. California-Arizona-Nevada}

California, Arizona, and Nevada are adjoining states with a high degree of labor and capital interchange. Nevada has no personal income tax; California ${ }^{104}$ and Arizona ${ }^{105}$ do. Their statutes are similar in the following significant particulars: (1) the definition of "resident" is identical; ${ }^{100}$ (2) both tax the entire income of residents and income of nonresidents earned within the state; ${ }^{107}$ neither taxes nonresident income from stocks, bonds, notes, or other intangible personal property unless the prop-

101 See HELLERSTEIN, op. cit. supra note 82, at 547.

102 See, e.g., GA. CoDE ANN. \$ 92-3329(b) (1961) ; VA. Code ANN. § 58-151.19

(Supp. 1962); VT. Stat. ANN. tit. 32, \$\$ 5769-70 (Supp. 1961).

103 Ga. Code Ann. \$ 92-3329(b) (1961).

104 See note 7 supra and accompanying text.

105 Ibid.

106 Compare Cal. Rev. \& Tax Code \$17014, with Artz. Rev. Star. Ann. §43-101(p) (1956). (1956).

107 Compare CaI. Rev. \& Tax Code § 17041, with Arrz. Rev. Stat. Ann. § 43-102 
erty has acquired a business situs within the state; ${ }^{108}$ (3) itemized deductions of nonresidents are limited to those related to the production of income within the state, ${ }^{109}$ and no deduction may be taken for income taxes; ${ }^{110}$ (4) full personal exemptions are afforded nonresidents; ${ }^{111}$ (5) both allow tax credits to residents ${ }^{112}$ and nonresidents. ${ }^{113}$ The rates of taxation, however, differ. ${ }^{114}$

California residents who earn income within Arizona are taxed on such income by both California and Arizona.115 Arizona, however, allows a credit for taxes paid to California on income earned within Arizona. ${ }^{116}$ Because Arizona has a higher rate of taxation, ${ }^{117}$ the California resident must still pay Arizona a tax approximating the difference between the Arizona and California tax rates. This sum reflects only the higher Arizona tax rate and is not double taxation.

Since California and Arizona residents pay no tax to Nevada for income earned there, California and Arizona taxation of this income cannot impose a double tax burden. Similarly, although Nevada residents will be taxed by California and Arizona on income earned in those states, ${ }^{118}$ they will not pay any tax to Nevada.

Both California' and Arizona tax income earned by Arizona residents within California. ${ }^{119}$ But because of Arizona's tax credit provisions, ${ }^{120}$ the Arizona resident will receive a resident tax credit from Arizona, rather than a nonresident credit from California. The lower California tax rate ${ }^{121}$ will result in an Arizona tax credit for the full amount of the California tax, and no multiple burden will result.

In this three state area, therefore, there will be no burden caused by multi-state taxation of the same income. In addition, the substantial uniformity of the tax acts of California and Arizona alleviates the taxpayers'

108 Compare Cal. Rev. \& Tax Code \$17952, with Ariz. Rev. Stat. ANn. \$43-114(b) (1956). (1956).

109 Compare Cal. Rev. \& Tax Code § 17301, with Ariz. Rev. Stat. ANn. § 43-125

110 Compare Cal. Rev. \& Tax Code $\$ 17204(b)(2)$, with ArIz. Rev. Stat. Ans. $\S 43-123$ (c) (1) (1956).

111 Compare Cal. Rev. \& Tax Code § 17181, with ARIz. Rev. Stat. ANn. § 43-127 (Supp. 1962).

112 Compare Cal. Rev. \& Tax Code §18001, with Arrz. Rev. Stat. Ann. §43-128(a) (1956).

113 Compare CaI. Rev. \& TAx Code \$18002, with ArIz. Rev. Stat. Ans. $\$ 43-128$ (b) (1956). The Arizona nonresident credit does not depend on reciprocity as does the California credit. Ibid.

114 Compare Cal. Rev. \& Tax Code $\$ 17041$, with ArIz. Rev. Stat. Ann. \$ 43-102(a) (1956).

115 See note 97 supra and accompanying text.

116 See note 113 supra and accompanying text.

117 See note 114 supra.

118 See note 107 supra and accompanying text.

119 See note 107 supra and accompanying text.

120 ArIz. Rev. STAt. ANN. \$43-128(a) (1956) allows a resident a credit regardless of whether the foreign state would also allow him a credit.

121 See note 114 supra. 
burden of acquainting himself with differing tax systems. However, the unusual operation of Arizona's credit provision which allows residents to take credits in Arizona, even though they are entitled to another state's nonresident credit, unnecessarily diminishes Arizona's tax revenue without contributing to the reduction of multiple taxation.

\section{B. Minnesota-Wisconsin-Iowa}

Minnesota, Wisconsin, and Iowa are contiguous states, each of which taxes individual income. ${ }^{122}$ Their tax acts contain significant differences and similarities. The definition of resident in each is equivalent to domicile in the traditional sense. ${ }^{123}$ Minnesota ${ }^{124}$ and Iowa ${ }^{125}$ utilize federal income tax calculations, whereas Wisconsin ${ }^{126}$ does not. All three tax entire net income of residents and income of nonresidents from sources within the state; ${ }^{127}$ the rates of taxation, however, differ. ${ }^{128}$ All three states allow both proportionate deductions for expenses not connected with the production of income and deductions for income taxes paid to the state of residence ${ }^{129}$ as well as the usual deduction related to the production of income. Wisconsin also permits a deduction for certain income taxes paid it. ${ }^{130}$ Each state allows varying amounts, ${ }^{131}$ characterized as "personal exemptions," to be credited against its tax; ${ }^{132}$ Iowa allows nonresidents the same personal credit as residents, whereas Wisconsin and Minnesota require proration. ${ }^{133}$ Iowa residents are permitted to credit taxes paid on income earned outside the state; ${ }^{134}$ Minnesota ${ }^{135}$ and Wisconsin, ${ }^{136}$ on the other hand, give a resident credit for taxes paid to another state on income derived from personal services rendered there. Wisconsin has a provision exempting income from personal services rendered by a person not domiciled within the state if the domiciliary state affords a similar exemption. ${ }^{137}$

122 See note 7 supra and accompanying text.

123 Compare Minn. Stat. Ann. \$290.01(7) (1962) and Wis. Star. Ann. \$71.01(1) (Supp. 1963), with IowA CoDE ANN. \$ 422.4(8) (1949).

124 MinN. Stat. ANN. $\$ 290.01(20)$ (1962).

125 Iowa Code ANn. $\$ 422.4$ (1) (Supp. 1962).

126 Wis. Stat. ANN. $\$ 71.03$ (1957).

127 Compare Mrnn. Stat. Ann. $\$ 290.03(2)$ (1962) and Wis. Stat. Ann.

$\S 71.01$ (1) (Supp. 1963), with Iowa Cope ANN. \$ 422.5 (Supp. 1962).

128 Compare Minn. Stat. Ann. \$290.06(2) (1962) and Wis. Stat. AnN. \$ 71.09

(Supp. 1963), with IowA Code ANN. \$422.5 (Supp. 1962).

129 Compare Minn. Stat. Anv. $\$ 290.18$ (1962) and Wis. Stat. ANN. $\$ 71.05$

(Supp. 1963), with IowA Code ANn. \$ 422.9(4) (Supp. 1962).

130 Wis. Stat. Ann. §71.05(4) (Supp. 1963).

131 Compare Wis. Stat. Ann. \$71.09(6) (1957) and Minn. Stat. Ann.

$\S 290.06(3)$ (1962), with Iowa Code ANN. \$422.12 (Supp. 1962).

132 Ibid.

133 Ibid.

134 Towa Code ANn. \$422.8(1) (Supp. 1962).

135 Minn. Stat. AnN. $\$ 290.081$ (1962).

136 Wis. Stat. Ann. § 71.05(5) (Supp. 1963).

137 Wrs. Star. ANN. \&71.03(2) (f) (Supp. 1963). 
Because Iowa and Minnesota have not reciprocated, the exemption does not affect their residents.

Minnesota residents who derive income from either Iowa or Wisconsin are taxed by those states, ${ }^{138}$ and receive no credit for Minnesota taxes. But a Minnesota resident is entitled to a resident credit from Minnesota for taxes paid another state on income derived from personal or professional services. However, he will be doubly taxed to the extent that he has Iowa or Wisconsin income not derived from those services. ${ }^{139} \mathrm{~A}$ Wisconsin resident earning income in one of the other states will be subject to the same multiple taxation. ${ }^{140}$

Iowa residents earning income in Wisconsin and Minnesota must pay a nonresident tax to those states, ${ }^{141}$ and will receive no credit for taxes paid to Iowa. But because Iowa permits a resident credit for taxes paid in other states, ${ }^{142}$ an Iowa resident will not be subject to any multiple taxation of income taxed by Minnesota or Wisconsin. He will, however, pay an amount reflecting the higher tax rates ${ }^{143}$ of Minnesota or Wisconsin since Iowa limits the credit to an amount that would have been due Iowa on a like amount of income. ${ }^{144}$

Due to the limited operation of Minnesota and Wisconsin resident credits, residents of those states will be subject to some multiple taxation. In addition, the multi-state taxpayer will have the added burden of informing himself about the differing tax structures of each of the states.

\section{Virginia-Maryland-District of Columbia}

Multi-state contacts are prevalent in the District of Columbia, and become further exaggerated when domiciliaries of other states migrate to the capital in pursuit of government employment but reside in Virginia or Maryland. Both the Virginia ${ }^{145}$ and Maryland ${ }^{146}$ tax statutes define resident to include not only domiciliaries but also every person maintaining a place of abode within the state for more than six months within the past year. The tax laws of those two states are also similar in the following particulars: (1) residents are taxed on entire income; 147 (2) nonresidents are taxed on income earned within the state; ${ }^{148}$ (3) nonresidents are al-

138 See note 127 supra and accompanying text. 139 See note 135 supra and accompanying text. 140 See note 136 supra and accompanying text. 141 See note 127 supra and accompanying text. 142 See note 134 supra and accompanying text. 143 See note 128 sipra and accompanying text. 144 See note 134 supra. 145 VA. CODE ANN. \$58-77(8) (1959).

146 MD. ANN. Cone art. 81, §279(i) (Supp. 1962); see Reiling v. Lacy, 93 F. Supp. 462 (D. Md. 1950).

147 Compare VA. Code Ans. §58-101 (Supp. 1962), with Mo. Ann. Code art. 81, §288(c) (1) (Supp. 1962). 148 Ibid. 
lowed proportional personal exemptions ${ }^{149}$ and deductions related to the production of income within the state; ${ }^{150}$ (4) residents are allowed a credit for taxes paid another state on income earned there; ${ }^{151}$ (5) nonresidents are allowed a reciprocal credit for taxes paid the resident state on income earned in the credit state. ${ }^{1.52}$

The District of Columbia defines resident to include domiciliaries and persons who maintain a place of abode within the District for more than seven months of the taxable year. ${ }^{153}$ However, it excludes from this category certain elective and appointive officials of the federal government. ${ }^{154}$ Residents of the District are taxed on their entire income. ${ }^{155}$ But if a District resident is a bona fide domiciliary of another state, he is allowed to credit against his District tax all income and intangible personal property taxes paid to his state of domicile..$^{156}$

Domiciliaries of other states employed in the District for an indefinite time and living in Virginia or Maryland for more than six months of the taxable year will be taxed as residents of those states ${ }^{157}$ and possibly by their state of domicile, but will not be taxed by the District. 158 Residents of the District earning income in Virginia will be subject to that state's nonresident tax..$^{159}$ However, since the District does not tax Virginia residents, ${ }^{100}$ residents of the District are apparently eligible for Virginia's nonresident credit which requires either reciprocation for or non-taxation of its residents. ${ }^{161}$ Income of District residents derived from wages or other compensation for personal services performed in Maryland is exempt from Maryland tax. ${ }^{162}$ Maryland will tax income from other sources ${ }^{163}$ but a nonresident credit appears to be available to District residents, ${ }^{164}$ who

149 Compare VA. Code ANN. \$58-98(d) (1959), with MD. ANN. Code art. 81, $\S 286(\mathrm{~h})$ (1957). (1957).

150 Compare VA. Code Ann. §58-82 (1959), with Md. ANn. Code art. 81, §286(h)

151 Compare VA. Code Ans. \$58-103 (Supp. 1962), with Md. Ann. Code art. $81, \S 290$ (1957).

152 Compare VA. Code ANn. §58-104 (Supp. 1962), with Md. ANn. Code art. 81, §291 (a) (1957).

153 D.C. CoDe Ans. $\$ 47-1551$ c(s) (1961); see District of Columbia v. Murphy, 314 U.S. 441 (1941).

154 Ibid.

155 D.C. Code ANN. \$47-1567 (1961).

156 D.C. Code AnN. §47-1567d(a) (1961).

157 See notes 145-47 supra and accompanying text.

158 See note 10 supra and accompanying text.

159 See note 148 supra and accompanying text.

160 See note 10 supra and accompanying text.

161 VA. Code ANn. \$58-104 (Supp. 1962).

162 See Md. AnN. Code art. 81, §291(b) (1957).

163 See note 148 supra.

164 See Mo. Ann. Code art. 81, §291(a) (1957). 
therefore seem not to be subject to double taxation on income earned in Maryland or Virginia.

Maryland and Virginia residents earning income in the other state are subject to a nonresident tax. ${ }^{165}$ However, since both states have reciprocal nonresident credit provisions, ${ }^{166}$ they will accord a credit to each other's residents, and no multiple taxation will result.

In these three jurisdictions, therefore, there is no burdensome lack of uniformity. Double taxation exists only to the extent that persons taxed by their domiciliary states reside in and are taxed by Maryland or Virginia. The tax statutes of the District of Columbia seem to preclude its participation in double taxation, and in fact in some cases afford relief from taxation when there is no possible double taxation. ${ }^{167}$

\section{ConcLusion}

The regional examples support the conclusion that although the burden of multi-state taxation has not been completely eliminated, its impact has been greatly reduced. The most effective device has been the allowance of resident and nonresident credits ${ }^{168}$ which not only reduce multiple taxation but also enable the states to impose limitations which tend to restrict the allowance of the credit to cases of actual double taxation. Many of the other devices which alleviate double taxation, for example, the allowance of liberal deductions and exemptions, operate irrespective of actual double taxation, and may serve only to diminish the state's tax revenue, while only insubstantially affecting multiple taxation.

The attitude of restraint that the states have exhibited in the use of their taxing power and the degree of success thus far achieved in the alleviation of the burden of multiple taxation confirms the wisdom of the Supreme Court in leaving the problem to be worked out by the states and in declining to read into the fourteenth amendment a prohibition against multiple taxation. ${ }^{169}$

However, a greater measure of uniformity ${ }^{170}$ in state taxing statutes than now exists would reduce the multiple taxation caused by conflicting definitions, and would diminish the taxpayer's burden of informing himself of different tax systems. Greater uniformity might be achieved in several ways. One writer has suggested a constitutional amendment empowering

165 See note 148 supra and accompanying text.

166 See note 152 supra and accompanying text.

167 See note 27 supra.

168 See Caruso, State Taxation of the Income of Nonresidents: A Neze Jersey Dilemma, 15 RutGERs L. REv. 311, 315, 318-19 (1961); Starr, Reciprocal and Retaliatory Legislation in the American States, 21 MrNN. L. Rev. 371, 402-03 (1937) in which the author concluded that resident credit does not avoid double taxation as well as nonresident reciprocal credits.

"The conflicting crediting devices and the wide variation in their scope have produced inequitable results; greater uniformity among the states would produce greater equity among taxpayers." Hellerstern, Cases on State and Local TAXATION 561 ( 2 d ed. 1961).

169 See note 13 supra and accompanying text.

170 See Caruso, supra note 168, at 318-19. 
general congressional supervision of state income taxation.171 However, in light of the steps already taken by the states, such drastic federal intervention does not seem warranted, and Congress might well find it difficult, impractical, and improvident to exercise the power of supervision. Another suggestion is the promulgation of a uniform state income tax statute for adoption by all taxing states. ${ }^{172}$ Although this solution is potentially capable of fostering the greatest uniformity, it too suffers from the defect of impracticality. Not only do state income tax statutes reflect underlying economic, social, and political policies that may be peculiar to each jurisdiction, but the income tax is also only one component of an overall tax scheme, which may include a sales, property, per capita, or other tax. States blend these ingredients in differing proportions, and the blending will affect the state's attitude toward its income taxation. In addition, states very often use tax legislation as a competitive device to attract labor, capital, and residents from sister states. For all of these reasons, widespread adoption of a uniform tax act appears improbable and state-by-state modification of a uniform act would, of course, disserve the underlying purpose of uniformity.

A more feasible alternative is regional cooperation among several neighboring states since it is among these groupings that the bulk of the multiple tax inequalities will arise. ${ }^{173}$ An interstate conference composed of representatives of each state in the region would form the nucleus of the cooperative venture. The primary objectives of the conference would include study of the causes of tax inequality resulting from varying tax statutes, negotiation of compromise solutions to the problems found, and reference of suggested reforms to the respective legislatures for adoption. Agreements for the exchange of information among state tax officers and plans to eliminate duplicate administration and reporting could also provide subjects for negotiation. Unlike federal intervention or a uniform tax act, regional cooperation will permit each of the participating states to protect its own interests and to relinquish these interests in return for reciprocal concessions by the other states. A scheme of state cooperation is also more consistent with the nature of the federal system in that it will allow each state to retain control over its internal tax affairs. Because income tax legislation deals with a vital interest of every state-the production of revenue-, the mechanism of bargaining for concessions that is involved in regional cooperation offers the most practical alternative for furthering greater uniformity in state tax statutes, thereby eliminating the remaining inequality caused by multi-state income taxation.

Daniel C. Soriano, Jr.

171 See Caruso, supra note 168 , at 320 .

172 See Tully, The Tax Credit, in N.Y. State Tax Coma'n, SPECIal Report 84 (No. 15, 1958); Caruso, supra note 168, at 318; note 168 supra.

173 For an example of a fairly successful interstate conference involving New York, New Jersey, and Connecticut, see HeLlERSTEIN, op. cit. supra note 168, at 548-49. 